\title{
Assessment of schistosomiasis in the semi-arid Northeast region of Brazil: the São Francisco River large-scale water transposition project
}

\author{
Tereza Cristina Favre ${ }^{[1]}$, Monica Ammon Fernandez ${ }^{[2],}$ \\ Lilian Christina Nóbrega Holsbach Beck ${ }^{[1]}$, Ricardo José de Paula Souza Guimarães ${ }^{[3]}$, \\ Otávio Sarmento Pieri[ ${ }^{[1]}$ and Silvana Aparecida Carvalho Thiengo ${ }^{[2]}$
}

[1]. Laboratório de Educação em Ambiente e Saúde, Instituto Oswaldo Cruz, Fundação Oswaldo Cruz, Rio de Janeiro, Rio de Janeiro, Brasil. [2]. Laboratório de Malacologia, Instituto Oswaldo Cruz, Fundação Oswaldo Cruz, Rio de Janeiro, Rio de Janeiro, Brasil. [3]. Laboratório de Geoprocessamento, Instituto Evandro Chagas, Ministério da Saúde, Ananindeua, Pará, Brasil.

\begin{abstract}
Introduction: Risk of schistosomiasis expansion to semi-arid northeastern Brazil under the influence of the Integration Project of the São Francisco River (IPSFR) was assessed. Methods: Stool examinations of schoolchildren, epidemiological investigation, and survey of the local host snail Biomphalaria straminea were performed in five IPSFR municipalities. Results: Six of 4,770 examined schoolchildren were egg-positive for Schistosoma mansoni. Biomphalaria straminea was widespread, but not naturally infected with $S$. mansoni. Snails experimentally exposed to two laboratory $S$. mansoni strains yielded infection indices of $1-4.5 \%$. Conclusions: There is evidence of active schistosomiasis transmission in the area; thus, intensive surveillance actions are required.
\end{abstract}

Keywords: Integration Project of the São Francisco River. Epidemiological survey. Biomphalaria straminea.

The Integration Project of the São Francisco River (IPSFR) aims to increase the water resources in the semi-arid regions of the States of Pernambuco, Ceará, Rio Grande do Norte, and Paraiba, thus benefiting 12 million people. The project captures $1.4 \%$ of the river's flow and divides it into the Eastern and Northern Axes (Figure 1).

Watershed connections can create eco-bio-social changes that may boost the introduction and spread of diseases, including schistosomiasis $^{(1)(2)}$. Infection by Schistosoma mansoni has been recorded throughout the São Francisco River, and several municipalities that lie on its banks and tributaries have a history of high infection rates.

The distribution maps of snail hosts and schistosomiasis show that there are snail populations in many areas without any record of the disease ${ }^{(3)}$; however, these areas are likely to become endemic as a result of environmental and socioeconomic changes ${ }^{(4)}$. In Northeastern Brazil, two snail species are associated with schistosomiasis transmission: Biomphalaria glabrata, which occurs mostly in the coastal and rainforest areas, and Biomphalaria straminea, which is widely distributed and is the main host species in the semi-arid Northeast ${ }^{(5)}$.

Corresponding author: Dra. Tereza Cristina Favre.

e-mail: tfavre@ioc.fiocruz.br

Received 17 July 2015

Accepted 8 September 2015
The Ministry of Health $(\mathrm{MoH})$ considers the IPSFR area vulnerable to schistosomiasis transmission because it harbors populations of the intermediate hosts and favors the settlement of people from endemic areas. It recommends that vulnerable areas be mapped and surveyed for snail hosts and egg-positive people, aiming to prevent the establishment of transmission ${ }^{(3)}$. Furthermore, stool surveys should target school-aged children because the prevalence in that age group is a suitable indicator of the community prevalence ${ }^{(6)}$.

This study aimed to assess the occurrence of or the potential risk of active transmission of schistosomiasis in five municipalities involved in the integration of the São Francisco River's North Axis. Thus, we performed stool examinations in schoolchildren to identify disease cases and verified the occurrence of naturally infected snails in addition to testing the susceptibility of local B. straminea to $S$. mansoni laboratory strains.

A technical visit in July 2010 started in Sobradinho, State of Bahia, during which several municipalities in the IPSFR area of influence were investigated to determine the presence of Biomphalaria spp. and to select the municipalities that would participate in the parasitological survey.

The selection of municipalities was based on the following criteria: a) presence of snail hosts; $b$ ) history of schistosomiasis based on data from the Information System for Notifiable Diseases [Sistema Nacional de Agravos de Notificação (SINAN)] and/or local health teams; c) presence of basins with eco-epidemiological characteristics indicative of transmission 


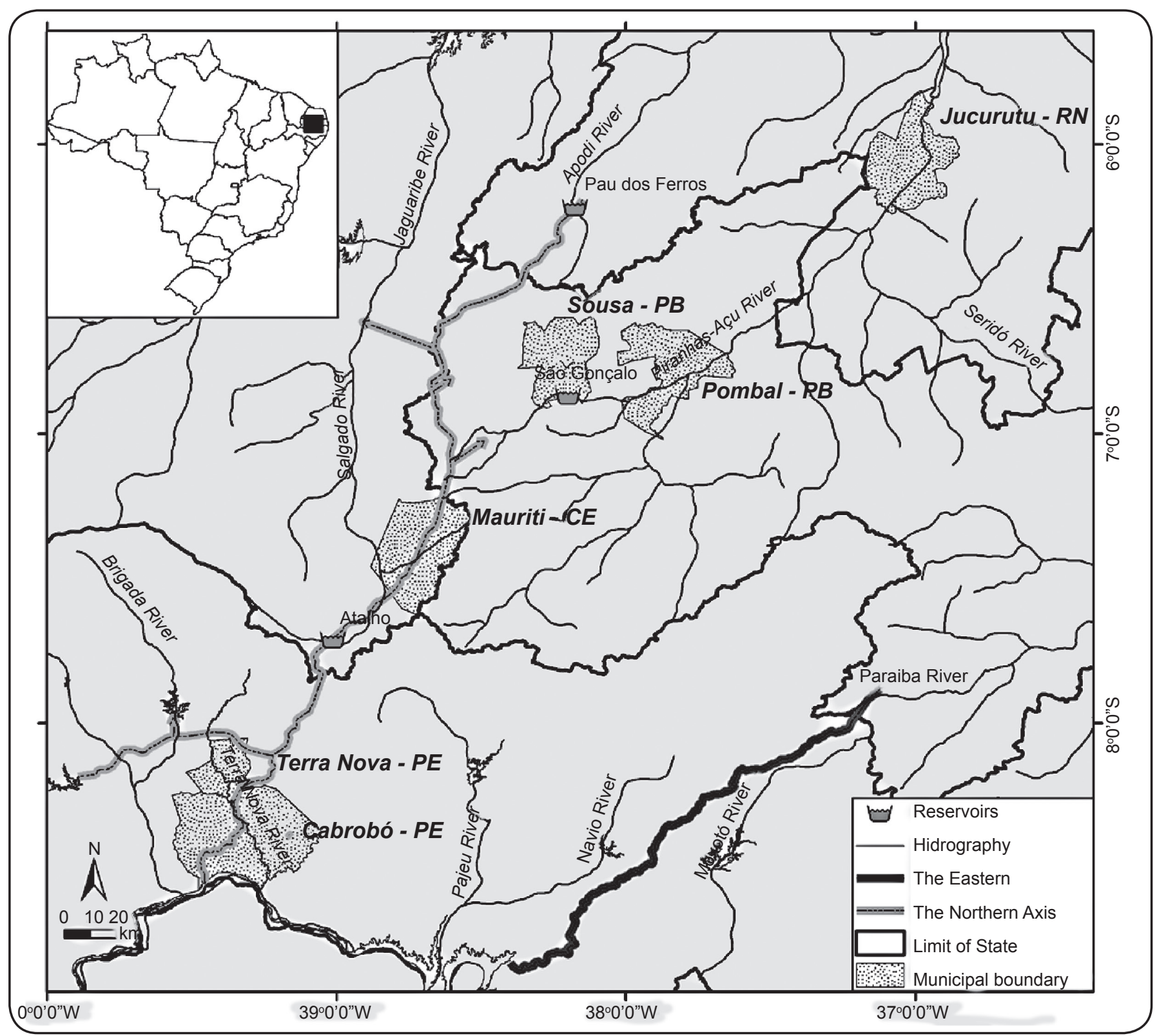

FIGURE 1 - Sketched map of the study area. The Northern and Eastern Axes of the Integration Project of the São Francisco River are shown as thick light or dark gray lines, respectively.

or the potential risk of installing schistosomiasis foci; and d) consent of the local health and education managers to conduct a school survey with children aged 6-15 years.

All of the elementary students in the 62 urban and rural schools of the selected municipalities were included in the parasitological survey, except in the cases of São Gonçalo/Sousa and Palestina/Mauriti, in which only the schools in the districts of São Gonçalo/Sousa and Palestina/Mauriti, respectively, were included (Table 1). In those two municipalities, the risk of transmission was known to be limited, and the cost-benefit analysis did not justify the inclusion of all schools in the survey. School records were provided by the Municipal Secretary of Education.
In January 2011, two professionals from each municipality participated in a training course on schistosomiasis covering all stages of parasitological survey. The trained professionals were involved in the school survey in their municipality.

The parasitological examinations were performed between April 2011 and June 2012. In each municipality, stool vials were distributed to all enrolled schoolchildren and collected the next day. The samples were taken to the laboratory and prepared the same day using the Kato-Katz method (a sample with two slides) $)^{(7)}$.

As recommended by the $\mathrm{MoH}^{(3)}$, the egg-positive children were treated with a single dose of praziquantel $(60 \mathrm{mg} / \mathrm{kg})$ in the local health unit under medical supervision. All of the 
TABLE 1 - Survey of schistosomiasis infection in five municipalities of the Integration Project of São Francisco River.

\begin{tabular}{|c|c|c|c|c|c|c|c|c|}
\hline \multirow[b]{2}{*}{ Municipality (State) } & \multirow{2}{*}{$\begin{array}{l}\text { pulation (\% as schoc } \\
\text {-aged children)* }\end{array}$} & \multirow{2}{*}{$\begin{array}{c}\text { Area } \\
\text { surveyed }\end{array}$} & \multirow{2}{*}{$\begin{array}{l}\text { Schools } \\
\text { (n) }\end{array}$} & \multicolumn{3}{|c|}{ Schoolchildren } & & \\
\hline & & & & eligible & examined & infected & examined & infected \\
\hline Sousa (Paraíba) & $65,803(13.0)$ & São Gonçalo District & 5 & 1,075 & 857 & 3 & 79.7 & 0.4 \\
\hline Mauriti (Ceará) & $44,240(17.0)$ & Palestina District & 8 & 927 & 616 & 0 & 66.4 & 0.0 \\
\hline Total & $169,123(14.1)$ & 62 & 6,804 & 4,770 & 6 & 70.1 & 0.13 & \\
\hline
\end{tabular}

*2010 Census (http://ibge.gov.br/cidadesat/xtras/home.php).

patients' epidemiological information (diagnostic outcome, parasite load, place of residence, treatment, stool tests to assess parasitological cure after three months of treatment, and evaluation of autochthony) was sent for notification to the SINAN by an epidemiologic surveillance professional. Trained professionals and the local health team were responsible for conducting the stool examinations and cure evaluations. The study was approved by the Research Ethics Committee/Oswaldo Cruz Foundation [Comitê de Ética em Pesquisa/Fundação Oswaldo Cruz (CEP/FIOCRUZ: protocol 579/10)].

Natural snail breeding sites, preferably near schools in the five selected municipalities, were surveyed in July and October 2010, May and November 2011, and October 2012. The geographic coordinates of both the school address and breeding sites of the Biomphalaria snails were captured using a handheld Global Positioning Systems (GPS) receiver (Garmin Etrex Vista) and imported into a Geographic Information System (GIS) for visualization of their spatial distribution ${ }^{(8)}$.

The collected snails were identified and examined for $S$. mansoni larval forms according to the routine techniques of the National Reference Laboratory of Medical Malacology, FIOCRUZ $^{(9)}$.

Biomphalaria straminea descending from snails collected in each studied municipality were individually exposed to five $S$. mansoni miracidia from the two strains (BH and EC strains), which were obtained from laboratory colonies of $B$. glabrata from Belo Horizonte, State of Minas Gerais (BH strain) and from Pontezinha, State of Pernambuco (EC strain) and obtained from female Swiss albino mice ${ }^{(10)}$. As controls, B. glabrata from Belo Horizonte and Pontezinha laboratory colonies were infected. All procedures followed the guidelines established by the Committee for the Ethical Use of Animals [(CEUA) - license CEUA LW-31/10] of FIOCRUZ.

In total, 4,770 schoolchildren underwent stool examinations, of which six $(0.13 \%)$ were egg-positive: one in Terra Nova (6 eggs/g feces [epg]), three in São Gonçalo/Sousa (54 epg, $36 \mathrm{epg}$, and $6 \mathrm{epg}$ ), and two in Jucurutu (30 epg and $6 \mathrm{epg}$ ). The mean egg load of the positive stool samples was $23 \mathrm{epg}$. The overall stool examination coverage was $70.1 \%$. The highest participation rate was observed in Terra Nova, and the lowest participation occurred in Jucurutu (Table 1). The mean distances among positive cases were $60 \mathrm{~m}$ in Jucurutu and $20-900 \mathrm{~m}$ in São Gonçalo/Sousa (Figure 2). All egg-positive children were treated and tested egg-negative when assessed for cure after three months of treatment.

After exhaustive collection from breeding sites close to schools and the homes of schoolchildren who were positive for S. mansoni, parasitological analyses of 4,591 B. straminea snails (Jucurutu, 2,319; Terra Nova, 917; São Gonçalo/Sousa, 770; Palestina/Mauriti, 263; and Pombal, 322) revealed no presence of the larval stage of $S$. mansoni.

The distribution area of schistosomiasis cases coincided with the breeding sites of $B$. straminea in Jucurutu, Terra Nova, and São Gonçalo/Sousa, separated by distances of 300-400m, 150$450 \mathrm{~m}$, and 25-600m, respectively (Figure 2). Palestina/Mauriti and Pombal had no infected schoolchildren.

Eight $(1.7 \%)$ of the 461 B. straminea exposed to $S$. mansoni miracidia specimens became infected: one (1\%) of 96 from Jucurutu, five (4.6\%) of 109 from Palestina/Mauriti, and two (2.7\%) of 73 from São Gonçalo/Sousa. The highest rates of infection were obtained from specimens of B. straminea from Palestina/Mauriti (10\% with the BH strain) and São Gonçalo/ Sousa (5\% with the EC strain). No snails of the 79 from Pombal and the 104 from Terra Nova became infected. The mean \pm standard deviation duration of the precercarial period of $B$. straminea infected with S. mansoni was $36.6 \pm 4.6$ days. Six (2.8\%) specimens exposed to BH and $14(5.6 \%)$ specimens exposed to EC S. mansoni strains died during the experiment between the $29^{\text {th }}$ and $41^{\text {st }}$ days and between the $23^{\text {rd }}$ and $50^{\text {th }}$ days, respectively.

For the controls, $36(52.9 \%)$ of the 68 B. glabrata snails from Belo Horizonte and $27(56.2 \%)$ of the 48 B. glabrata snails from Pontezinha that were exposed to the BH and EC $S$. mansoni strains, respectively, became infected. The mean durations of the precercarial period in the Belo Horizonte and Pontezinha populations were $36.4 \pm 8.4$ days and $38.3 \pm 8.5$ days, respectively. Neither the specimens that survived for 60 days after exposure without shedding cercariae nor any of the dead snails showed larval stages of S. mansoni in their tissues. 


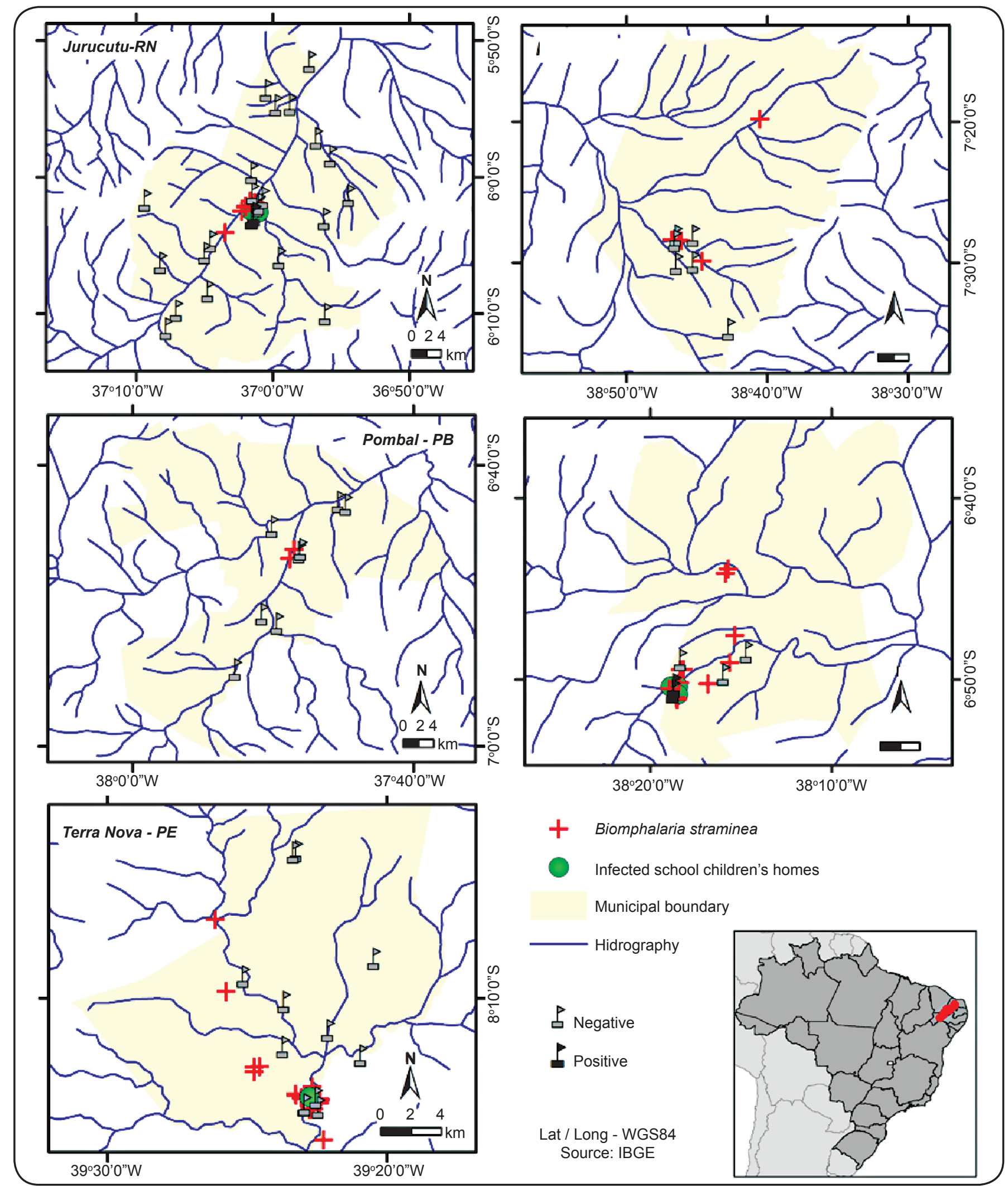

FIGURE 2 - Spatial distribution of the infected schoolchildren's homes and schools and the Biomphalaria straminea breeding sites in the five surveyed municipalities. 
The low rates of $B$. straminea experimentally infected agree with those in previous studies ${ }^{(11)}$. However, the presence of $B$. straminea in the breeding sites of the five study sites, susceptibility of specimens to experimental $S$. mansoni infection, and infected schoolchildren combined with poor home sanitary conditions indicate active schistosomiasis transmission in at least three of the five sites (Terra Nova, Jucurutu, and São Gonçalo/Sousa), even before water transposition. The spatial coincidence between $B$. straminea breeding sites and the residences of infected schoolchildren reinforces this inference. An epidemiological investigation, which included interviews with families, found that five of the six detected cases were autochthonous because the schoolchildren were born in the area where they lived at the time of the study, seldom left the city, and reported no contact with the water collections of an endemic municipality. However, they did swim, fish, and bathe in local bodies of water. The children's cohabitants were examined, and no other family member was egg-positive. In Palestina/Mauriti, no disease case was detected; however, surveys conducted in 1997 and 2002 recorded the presence of $23(0.37 \%)$ infection carriers from 6,196 exams (http://tabnet.datasus.gov.br/cgi/ deftohtm.exe?sinan/pce/cnv/pcebr.def), which supports the existence of environmental conditions that favor transmission.

The low percentage of S. mansoni cases is consistent with the epidemiological history of the study area, but may underestimate the real extent of the disease due to the poor sensitivity of the Kato-Katz method in low prevalence areas ${ }^{(12)}$. Furthermore, some of these municipalities have been targets of $\mathrm{MoH}$ control actions in the recent past.

Although B. straminea is considered less susceptible to infection with $S$. mansoni, it is able to maintain a high prevalence in endemic areas ${ }^{(13)}$. Additionally, the introduction of the highly susceptible $B$. glabrata through the continuous water supply provided by IPSFR cannot be ignored. Thus, we are faced at least with two factors that expose the local populations to a risk of infection.

Despite a small number of autochthonous cases, it indicates the existence of active transmission and should serve as a warning because the local rivers and dams receive inflow from the São Francisco River, allowing the disease to spread to the studied areas as well as the surrounding areas. The development and management of water resources are important risk factors for the onset of schistosomiasis; therefore, surveillance should be an integral part of planning, implementation, and operation of water projects in the future with the effective participation of health managers ${ }^{(14)(15)}$.

It is worrisome that health teams in the studied municipalities are not trained to implement the surveillance actions recommended in the technical guidelines ${ }^{(3)}$. Because the areas are not endemic for schistosomiasis, no active case searches occur, and in general, efforts are focused on the prevention and control of other diseases, such as dengue.

Despite the unquestionable benefit that the IPSFR will bring to the area, it presents a potential epidemiological risk to the local communities. If implemented without suitable preventive measures, it can facilitate the dispersion of snail hosts and the advent of schistosomiasis in areas previously considered free from the disease. Monitoring of the epidemiological situation in the municipalities with reported cases of schistosomiasis is highly recommended. This should be initiated at the early stages of the IPSFR and maintained throughout.

\section{ACKNOWLEDGMENTS}

We thank the Secretaries of Health and Education and in particular the professionals in the municipalities of Terra Nova (PE), Mauriti (CE), Sousa and Pombal (PB) and Jucurutu (RN) who contributed effectively to the realization of the study.

\section{CONFLICT OF INTEREST}

The authors declare that there is no conflict of interest.

\section{FINANCIAL SUPPORT}

Secretaria de Vigilância e Saúde, Ministério da Saúde (SVS/ MS) and Instituto Oswaldo Cruz, FIOCRUZ

\section{REFERENCES}

1. Rezende HR, Sessa PA, Ferreira AL, Santos CB, Leite GR, Falqueto AL. Effects of the installation of the Rosal hydroeletric powers station, Itabapoana River, States of Espírito Santo and Rio de Janeiro, on anophelinae, planorbidae and phlebotominae. Rev Soc Bras Med Trop 2009; 42:60-164.

2. Thiengo SC. Biodiversidade e Saúde Pública. In Aranda AT, Herzog MM, Thiengo SC (orgs). I Seminário sobre Gestão e Curadoria de Coleções Zoológicas da FIOCRUZ. Editora Corbã, Rio de Janeiro; 2011. p. 34-38.

3. Ministério da Saúde. Vigilância da Esquistossomose: Diretrizes Técnicas. 4a ed. Brasília: Secretaria de Vigilância em Saúde, Ministério da Saúde; 2014.

4. Thiengo SC, Fernandez MA. Moluscos límnicos em reservatórios de usinas hidroelétricas no Brasil: aspectos biológicos e epidemiológicos. In: Carvalho OS, Coelho PMZ, Lenzi HL (orgs). Schistosoma mansoni e Esquistossomose: Uma visão multidisciplinar. Editora FIOCRUZ, Rio de Janeiro: 2008. p. $435-57$

5. Carvalho OS, Scholte RGC, Amaral RS. Distribuição dos moluscos hospedeiros intermediários Schistosoma mansoni no Brasil, Biomphalaria glabrata, B. straminea e B. tenagophila. In: Amaral RS, Thiengo SC, Pieri OS (orgs). Vigilância e Controle de Moluscos de Importância Epidemiologica. Diretrizes Técnicas: Programa de Vigilância e Controle da Esquistossomose (PCE) 2a edição: Secretaria de Vigilância em Saúde, Ministério da Saúde, Brasília; 2008. p. 111-126.

6. Pereira APB, Favre TC, Galvão AF, Beck L, Barbosa CS, Pieri OS. The prevalence of schistosomiasis in school-aged children as an appropriate indicator of its prevalence in the community. Mem Inst Oswaldo Cruz 2010; 105:563-569.

7. Katz N, Chaves A, Pellegrino J. A simple device for quantitative stool thick-smear technique in Schistosoma mansoni. Rev Inst Med Trop São Paulo 1972; 14:397-400. 
8. Galvão AF, Favre TC, Guimarães RJPS, Pereira APB, Zani LC, Felipe KT, et al.. Spatial distribution of Schistosoma mansoni infection before and after chemotherapy with two praziquantel doses in a community of Pernambuco, Brazil. Mem Inst Oswaldo Cruz 2010; 105:555-562.

9. Fernandez MA, Thiengo SC, Amaral RS. Técnicas malacológicas. In: Amaral RS, Thiengo SC, Pieri OS (orgs). Vigilância e Controle de Moluscos de Importância Epidemiológica. Diretrizes Técnicas: Programa de Vigilância e Controle da Esquistossomose (PCE) 2 a edição: Secretaria de Vigilância em Saúde, Ministério da Saúde, Brasília; 2008. p. 43-70.

10. Fernandez MS. Schistosoma mansoni infections in the first three mouths of life of sympatric intermediate hosts from Brazil. Mem Inst Oswaldo Cruz 1997; 92:27-29.

11. Fernandez MA, Thiengo SC. Susceptibility of Biomphalaria straminea from Peixe Angical Dam, Tocantins, Brazil to infection with three strains of Schistosoma mansoni. Mem Inst Oswaldo Cruz 2010; 105:488-491.

12. de Vlas SJ, Gryseels B. Underestimation of Schistosoma mansoni prevalences. Parasitol Today 1992; 8:274-277.

13. Favre TC, Pieri OS, Zani LC, Ferreira JM, Domás GG, Beck L, et al. A longitudinal study on natural infection of Biomphalaria straminea and B. glabrata by Schistosoma mansoni in an endemic area of schistosomiasis in Pernambuco, Brazil. Mem Inst Oswaldo Cruz 2002; 97: 465-475.

14. Steinmann P, Keiser J, Bos R, Tanner M, Utzinger J. Schistosomiasis and water resources development: systematic review, metaanalysis, and estimates of people at risk. Lancet Infect Dis 2006; 6: 411-425.

15. Favre TC, Pereira APB, Galvão AF, Zani LC, Barbosa CS, Pieri OS. A rationale for schistosomiasis control in elementary schools of Rainforest Zone of Pernambuco, Brazil. PLoS Negl Trop Dis 2009; 3:e395.

\section{ERRATUM}

\section{Revista da Sociedade Brasileira de Medicina Tropical/Journal of the Brazilian Society of Tropical Medicine 49(2):252-257, Mar-Apr, 2016 - P.254}

TABLE 1 - Survey of schistosomiasis infection in five municipalities of the Integration Project of São Francisco River.

\begin{tabular}{|c|c|c|c|c|c|c|c|c|}
\hline \multirow[b]{2}{*}{ Municipality (State) } & \multirow{2}{*}{$\begin{array}{l}\text { pulation (\% as schoo } \\
\text {-aged children) } \%\end{array}$} & \multirow{2}{*}{$\begin{array}{c}\text { Area } \\
\text { surveyed }\end{array}$} & \multirow{2}{*}{$\begin{array}{l}\text { Schools } \\
\text { (n) }\end{array}$} & \multicolumn{3}{|c|}{ Schoolchildren } & & \\
\hline & & & & eligible & examined & infected & examined & infected \\
\hline Sousa (Paraíba) & $65,803(13.0)$ & São Gonçalo District & 5 & 1,075 & 857 & 3 & 79.7 & 0.4 \\
\hline Pombal (Paraíba) & $32,110(13.0)$ & Municipality & 9 & 722 & 447 & 0 & 61.9 & 0.0 \\
\hline Mauriti (Ceará) & $44,240(17.0)$ & Palestina District & 8 & 927 & 616 & 0 & 66.4 & 0.0 \\
\hline Total & $169,123(14.1)$ & 62 & 6,804 & 4,770 & 6 & 70.1 & 0.13 & \\
\hline
\end{tabular}

*2010 Census (http://ibge.gov.br/cidadesat/xtras/home.php).

Should read:

TABLE 1 - Survey of schistosomiasis infection in five municipalities of the Integration Project of São Francisco River.

\begin{tabular}{|c|c|c|c|c|c|c|c|c|}
\hline Municipality (State) & $\begin{array}{l}\text { opulation (\% as school } \\
\text {-aged children)* }\end{array}$ & $\begin{array}{c}\text { Area } \\
\text { surveyed }\end{array}$ & $\begin{array}{l}\text { Schools } \\
\text { (n) }\end{array}$ & eligible & examined & infected & examined & infected \\
\hline Sousa (Paraíba) & $65,803(13.0)$ & São Gonçalo District & 5 & 1,075 & 857 & 3 & 79.7 & 0.4 \\
\hline Pombal (Paraíba) & $32,110(13.0)$ & Municipality & 9 & 722 & 447 & 0 & 61.9 & 0.0 \\
\hline Mauriti (Ceará) & $44,240(17.0)$ & Palestina District & 8 & 927 & 616 & 0 & 66.4 & 0.0 \\
\hline Total & $169,123(14.1)$ & & 62 & 6,804 & 4,770 & 6 & 70.1 & 0.13 \\
\hline
\end{tabular}

*2010 Census (http://ibge.gov.br/cidadesat/xtras/home.php). 